\title{
Imprints of historical pollution and the 218-60 BCE tsunamigenic period in southwestern Spain
}

\author{
María Luz González-Regalado1,a, Guadalupe Monge², María Isabel Carretero², Manuel Pozo ${ }^{3}$, \\ Joaquín Rodríguez-Vidal, ${ }^{1, a}$, Luis Miguel Cáceres ${ }^{1, a}$, Manuel Abad ${ }^{4}$, Juan Manuel Campos ${ }^{5, a}$, \\ Javier Bermejo $^{5, a}$, Josep Tosquella ${ }^{1, a}$, Tatiana Izquierdo ${ }^{6}$, Maria Isabel Prudêncio ${ }^{7}$, \\ Maria Isabel Dias ${ }^{7}$, Rosa Marques ${ }^{7}$, Paula Gómez ${ }^{1, a}$, Antonio Toscano ${ }^{1, a}$, \\ Verónica Romero ${ }^{1, a}$, and Francisco Ruiz ${ }^{1,7, a, *}$
}

${ }^{1}$ Departamento de Ciencias de la Tierra, Universidad de Huelva, Av. Tres de Marzo, s/n, 21071-Huelva, Spain.

${ }^{2}$ Departamento de Cristalografía, Mineralogía y Química Agrícola, Universidad de Sevilla, C/ Profesor García González 1, 41012-Sevilla, Spain.

${ }^{3}$ Departamento de Geología y Geoquímica, Universidad Autónoma de Madrid, Av. Francisco Tomás y Valiente 7, 28049-Madrid, Spain.

${ }^{4}$ Departamento de Biología y Geología, Física y Química Inorgánica, ESCET, Universidad Rey Juan Carlos, Calle Tulipán s/n, 28933 - Móstoles, Spain.

${ }^{5}$ Departamento de Historia, Geografía y Antropología, Universidad de Huelva, Av. Tres de Marzo s/n, 21071-Huelva, Spain.

${ }^{6}$ Instituto de Investigaciones Científicas y Tecnológicas de la Universidad de Atacama, IDICTEC-UDA, Av. Copayapu, 485. Copiapó, Chile.

${ }^{7}$ Centro de Ciências e Tecnologias Nucleares (C2TN), Instituto Superior Técnico, Universidade de Lisboa, Estrada Nacional 10 (k 139.7), 2695-066-Bobadela LRS, Portugal.

${ }^{a}$ Centro de Investigación en Patrimonio Histórico, Cultural y Natural (CIPHCN), Universidad de Huelva, Facultad de Humanidades, Av. Tres de Marzo s/n, 21071 Huelva, Spain.

*ruizmu@uhu.es

\begin{abstract}
The Doñana National Park is a Biosphere Reserve located within the estuary of the Guadalquivir River (SW Spain). It is mainly composed of extensive fluvio-tidal marshes partially protected by an elongated sandy spit. Three phases have been distinguished in the late Holocene evolution of this spit based on textural, geochemical, palaeontological and, chronological data recorded in a long core (31 $\mathrm{m})$. Phase 1 ( $890 \mathrm{BCE}-218 \mathrm{BCE}$ ) is characterized by the alternation of lagoonal silty sediments and slightly polluted marsh deposits, the latter with contamination from thousand-year-old mining. Phase 2 (218 BCE-90 CE) is characterized by several historical tsunamis, which caused the erosion of previous dune systems and the deposit of these sandy sediments on the adjacent bottom of the lagoon. Phase 3 (90 CE-Present) includes a regressive sequence (lagoonal bottommarsh-dune system), with the pollution of lagoonal sediments due to Roman mining activities.
\end{abstract}

Key words: texture; heavy metals; Palaeontology; historical tsunamis; mining; Doñana; SW Spain.

\section{RESUMEN}

El Parque Nacional de Doñana es una Reserva de la Biosfera localizada dentro del estuario del río Guadalquivir (S.O. de España). Esta Reserva está formada principalmente por marismas fluvio-mareales parcialmente protegidas por una flecha arenosa alargada. Se han diferenciado tres fases en la evolución holocena tardía de esta flecha, con base en el análisis multidisciplinar (textura, geoquímica, paleontologíca, cronología) de un testigo largo (31 m). La fase 1 (890 BCE-218 BCE) se caracteriza por la alternancia de sedimentos lagunares limosos y depósitos de marisma levemente contaminados por metales pesados debido a una actividad minera milenaria. La fase 2 (218 BCE-90 CE) se distingue por la acción de varios tsunamis históricos, que causaron la erosión de sistemas dunares previos, así como el depósito de estos sedimentos arenosos sobre el fondo arcilloso de la laguna adyacente. La fase 3 (90 CE-actual) incluye una secuencia regresiva (laguna-marisma-sistema dunar) con una nueva contaminación de los sedimentos lagunares debido a las actividades mineras romanas.

Palabras clave: textura; metales pesados; paleontología; tsunamis históricos; minería; Doñana; S.O. España.

González-Regalado, M.L., Monge, G., Carretero, M.I., Pozo, M., Rodríguez-Vidal, J., Cáceres, L.M., Abad, M., Campos, J.M., Bermejo, J., Tosquella, J., Izquierdo, T., Prudêncio, M.I., Dias, M.I., Marques, R., Gómez, P., Toscano,A., Romero, V., Ruiz, F., 2020, Imprints of historical pollution and the 218-60 BCE tsunamigenic period in southwestern Spain: Revista Mexicana de Ciencias Geológicas, v. 37, núm. 1, p. 89-97. 


\section{INTRODUCTION}

In the last two decades, numerous studies have analyzed the historical and geological records of tsunamis (Ögretmen et al., 2015; Latcharote et al., 2018). Some of them have presented a review of the associated sedimentary deposits, its main features, and the dynamic processes involved in their formation (Dawson and Steward, 2007; Engel and Brückner, 2011). Others have focused on their sedimentary characteristics (Putra, 2018), their palaeontological record (Mamo et al., 2009; Ruiz et al., 2010) or their mineralogy (Pozo et al., 2010; Costa et al., 2015).

In this regard, trace metals are one of the most promising sentinels of tsunamigenic deposits both during the Holocene and nowadays (Veerasingam et al., 2014; Bianchette et al., 2016). Chemical signatures of (palaeo-)tsunamis have been reviewed in the last years, with exciting perspectives for the future development of this field (Chagué-Goff, 2010; Nelson et al., 2015). In addition, these trace metal concentrations of Holocene sediments have been used to obtain regional backgrounds and to distinguish historical periods of pollution (Xu et al., 2018).

This paper analyzes the Holocene geological record of a core extracted in the Doñana National Park, a Biosphere Reserve located in southwestern Spain. Its main purposes are to define possible tsunamigenic layers and their chronology, as well as to determine the impact of millennial mining activities in this currently protected area.

\section{STUDY AREA}

\section{The Doñana National Park}

The Doñana National Park is one of the most important wetlands in Europe. This UNESCO World Heritage Site covers more than 54000 ha., including the lowermost reach of the Guadalquivir river estuary. Most of its surface is formed by fluvial levees and fluvial-tidal marshes drained by ebb-tide channels (Figure 1). In some areas, these marsh-

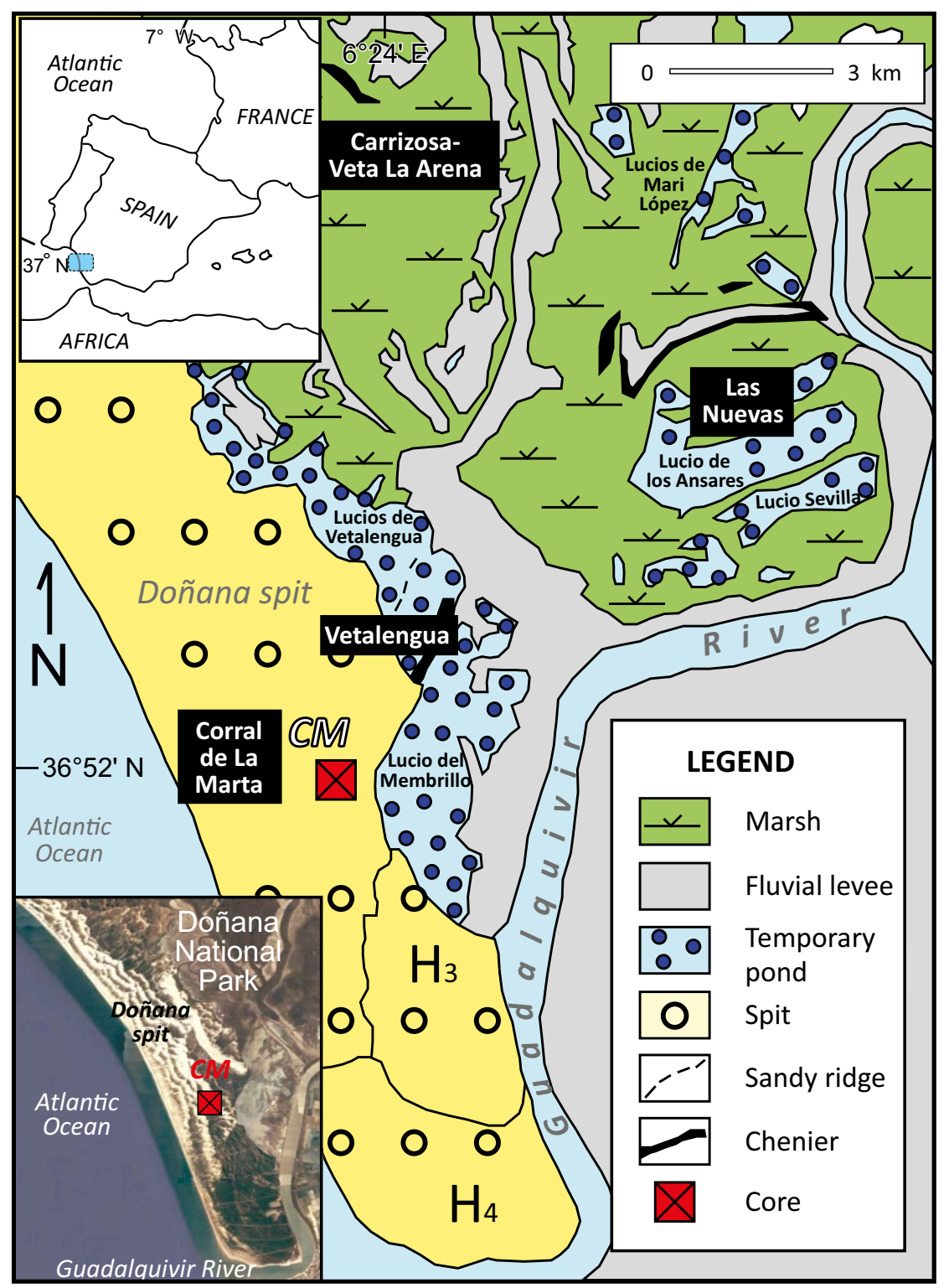

Figure 1. Main geomorphological features of the Doñana National Park, with location of the core studied. H3-H4: progradation phases (see text). 
lands are covered by cheniers and sandy ridges coming from the action of Holocene storms or tsunamis (Ruiz et al., 2004, 2005). Depressions among them are occupied by temporary ponds, locally so-called 'lucios'.

This internal geomorphological context is protected by an elongated littoral spit barrier (Figure 1: Doñana spit), which is constituted by dune systems and spit bars (Rodríguez-Vidal et al., 2014). The latter were mainly deposited during two regional progradation phases $\left(\mathrm{H}_{3}\right.$ : 2300-1100 cal. yr BP; $\mathrm{H}_{4}: 800$ cal yr BP-Present) (Zazo et al., 1994).

Hydrodynamic processes are controlled by the fluvial discharges, tidal regime, and littoral drift currents. The Guadalquivir River has a continuous inflow of ca. $10 \mathrm{~m}^{3} \cdot \mathrm{s}^{-1}$, with very high discharges associated with strong rainfall $\left(>1000 \mathrm{~m}^{3} \cdot \mathrm{s}^{-1}\right)$ (Sánchez et al., 2012). The tidal regime is mesotidal and semidiurnal, with an average tidal range of approximately $3.6 \mathrm{~m}$ (Borrego et al., 1993). Littoral drift currents transport sand-size sediments from the Portuguese coast to the Spanish nearshore zone (Cuena, 1991), causing the growth of the Doñana spit.

\section{Tsunami record in southwestern Spain}

The southwestern Iberian coast is a low-probability tsunamigenic area, with a prehistoric and historical record of some twenty tsunamis in the last 10000 years (Lario et al., 2011). The estuarine sedimentary sequences of Spain and Portugal contain tsunamigenic evidence (sandy ridges, bioclastic beds, washover fans) mainly from the tsunamis of two tsunamigenic periods: a) $218 \mathrm{BCE}-60 \mathrm{BCE}$, with three or four tsunamis (218 BCE, $210 \mathrm{BCE}, 209 \mathrm{BCE}, 60 \mathrm{BCE}$ ), depending on the historical sources consulted; and b) $1720 \mathrm{CE}-1761 \mathrm{CE}$, with six tsunamis (1722 CE, 1731 CE, 1755 CE -two tsunamis-, $1756 \mathrm{CE}, 1761 \mathrm{CE})$. This last period includes the 1755 Great Lisbon tsunami, one of the most destructive historical tsunamis in the world (Rodríguez-Vidal et al., 2011a; Ruiz et al., 2013a). Some of them have been detected in Holocene cores and shallow sections ( $<2 \mathrm{~m}$ thickness) of the Doñana National Park (Ruiz et al., 2004, 2005).

\section{Historical pollution}

The Iberian Pyrite Belt (200 miles long $\times 40$ miles wide) is one of the most important metallogenic provinces in the world, located in southern Portugal and southwestern Spain. Several mines have been exploited since the 3rd millennium BCE (Davis et al., 2000). Some of them are located near the Guadiamar River, a tributary of the Guadalquivir River, with mining activities for more than 4000 years (Hunt, 2003). Consequently, some rivers of this area are very polluted, with very shocking acid mine drainage processes (Olías and Nieto, 2015).

\section{MATERIAL AND METHODS}

A 31-m long core (Figure 1: CM) was recovered by the Instituto Geológico y Minero de España (IGME) near the so-called Corral de la Marta, located in the southeastern part of the Doñana spit. In a first step, the main lithological units were separated in a visual review of the core (texture, color, compaction, macropalaeontology). Ten samples were selected from the different units and divided into subsamples for specific analyzes (Figure 2a). The selection of these samples was based on: a) the presence of different sedimentary facies; b) the definition of its limits; c) the internal sedimentary structures; and d) the visual distribution of bioclasts in the core.

\section{Grain size}

The lithological description has been complemented with grainsize analysis (Figure 2b). Grain-size distribution was determined by wet sieving for the coarser fractions $(>100 \mu \mathrm{m})$. Fractions lesser than $100 \mu \mathrm{m}$ were analyzed by photo-sedimentation (MicromeriticsR
SediGraph 5100 ET). In both cases Na-hexametaphosphate was used as a dispersing agent.

\section{Chemical analysis}

Chemical analyses for trace metal elements were performed by Activation Laboratories, Ontario (Canada). Element concentrations were determined by instrumental neutron activation analysis [INAA] (As, $\mathrm{Co}, \mathrm{Cr}, \mathrm{Sc}$ ) and by inductively coupled plasma spectrometry [ICP] $(\mathrm{Cu}, \mathrm{Pb}$, ) or by multi-INAA-ICP techniques $(\mathrm{Ni}, \mathrm{Zn})$. The calibration is based on the analysis of over 30 international standard reference materials. Detection limits are $0.1 \mathrm{mg} \cdot \mathrm{kg}^{-1}(\mathrm{Sc}), 0.5 \mathrm{mg} \cdot \mathrm{kg}^{-1}(\mathrm{As}), 1 \mathrm{mg} \cdot \mathrm{kg}^{-1}$ (Co, $\mathrm{Cu}, \mathrm{Ni}, \mathrm{Zn}), 2 \mathrm{mg} \cdot \mathrm{kg}^{-1}(\mathrm{Cr})$ and $3 \mathrm{mg} \cdot \mathrm{kg}^{-1}(\mathrm{~Pb})$, respectively. Results were compared with a background recently obtained in silty-clayey sediments of the Doñana National Park (Figure 2c) (Carretero et al., 2011).

\section{Palaeontology}

The macrofossil record of 10 sub-samples was obtained by washing the bulk sediment $\left(12 \mathrm{~cm}^{3}\right)$ through a $1-\mathrm{mm}$ sieve. Bivalves and gastropods were identified to the species level and counted to study the semi-quantitative distribution in the core. In relation to the reduced amount of sediment studied, the abundance of a species in each sample was described as follows (Table 1 ): very rare (VR: 1 specimen), rare (R: 2-3 specimens); frequent (F: 4-6 specimens); abundant (A: 7-10 specimens); and very abundant (VA: $>10$ specimens). In addition, the main foraminifera of each facies have been recorded, although they have not been counted. Results were compared with those obtained from the ostracod assemblages of the same samples (Ruiz et al., 2013b).

\section{Radiocarbon dating}

Two radiocarbon dates were obtained at Beta Analytic Laboratories (Miami, USA) by AMS using samples of marine mollusk shells. These dates were calibrated (Table 2) using the Marine13 calibration (Reimer et al., 2013), with the reservoir correction determined for this area $(-108 \pm 31 \mathrm{yr})$ (Martins and Soares, 2013).

\section{RESULTS AND DISCUSSION}

\section{Sedimentary facies: interpretation}

Three facies have been distinguished, according to their textural features, sedimentary structures, palaeontological record and geochemical contents (Figure 2a):

Facies 1 (FA-1: greyish silt). It is constituted by pale yellow silts (Munsell's color value scale: $8 / 2$ to $8 / 3$ ), moderately sorted, with moderate percentages of clays (Figure 2b: 25-30\%) and scarce fine to very fine sands $(<8 \%)$. They present a very tenuous low-angle cross stratification, parallel lamination or absence of patent sedimentary structures. Macrofauna is abundant (Table 1), including numerous valves and fragments of marine bivalves (Chamelea gallina, Ruditapes decussatus, Acanthocardia tuberculata), gastropods (Rissoa sp., Lemintina arenaria) and scaphopods (Antalis vulgare, Dentalium sexangulum). Benthic marine foraminifera (Ammonia beccarii, Quinqueloculina spp., Elphidium crispum) are abundant.

The ostracod assemblage is dominated by marine species (Ruiz et al., 2013b), with numerous specimens of Urocythereis britannica, Pontocythere elongata and Palmoconcha turbida. Frequent individuals of brackish species (mainly Cyprideis torosa and Leptocythere tenera) are also present. This ostracod assemblages, the foraminiferal species and the macrofauna record already mentioned were usually found in the marine zones of perimediterranean lagoons, partially protected by sandy spits and located very close to the natural or artificial inlets (Ruiz et al., 2006a, 2016b). 


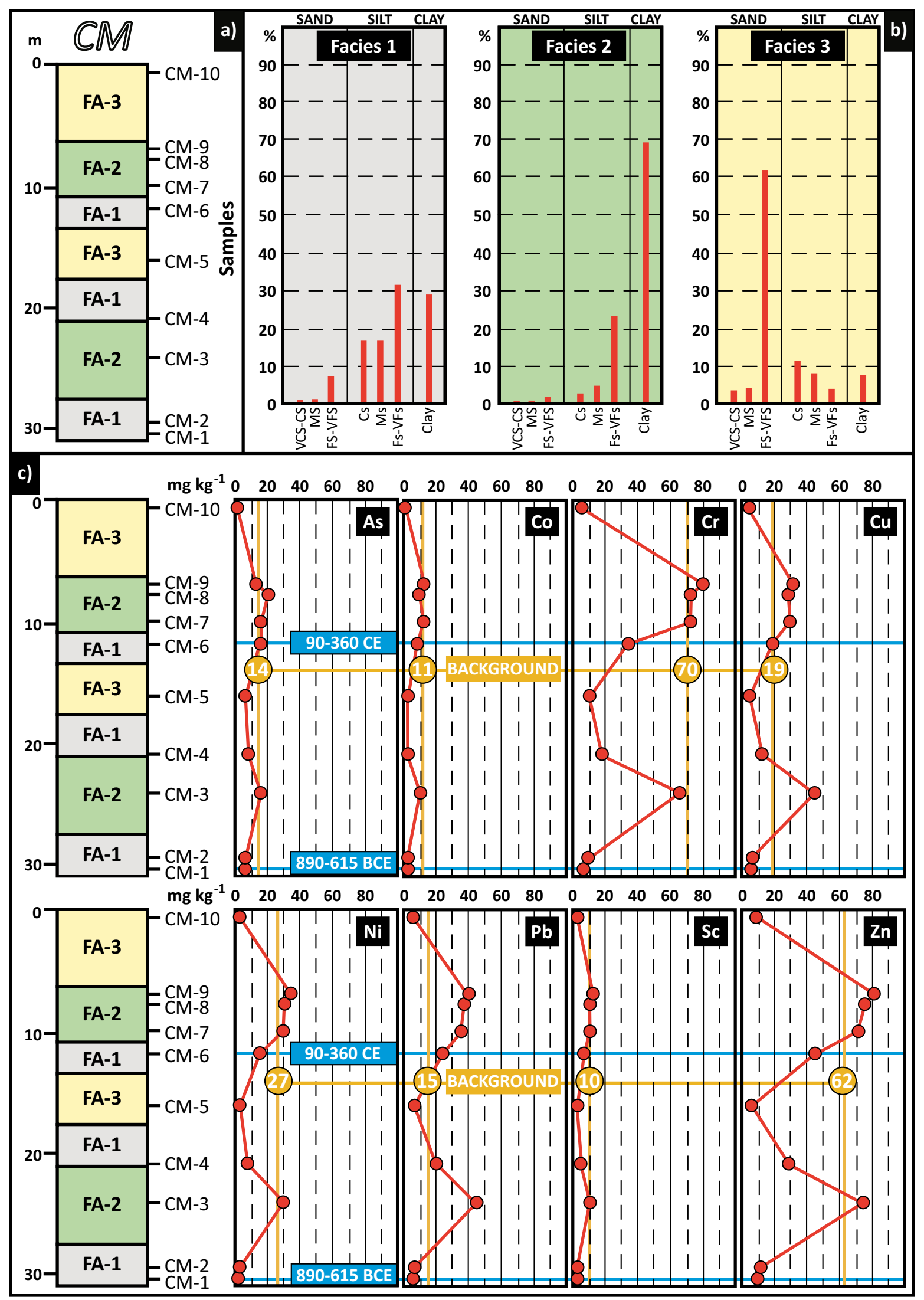

Figure 2. a: Core CM: facies and samples; b: Average grain size of the three facies differentiated; $c$ : Vertical distribution of trace metals in core CM, indicating the regional background (brown data) and the calibrated dates obtained (blue data). 
Table 1. Macrofauna record of core CM. Very rare (VR): 1 specimen; rate (R): 2-3 specimens; frequent (F): 4-6 specimens; abundant (A): 7-10 specimens; very abundant (VA): > 10 specimens. Grey: absence.

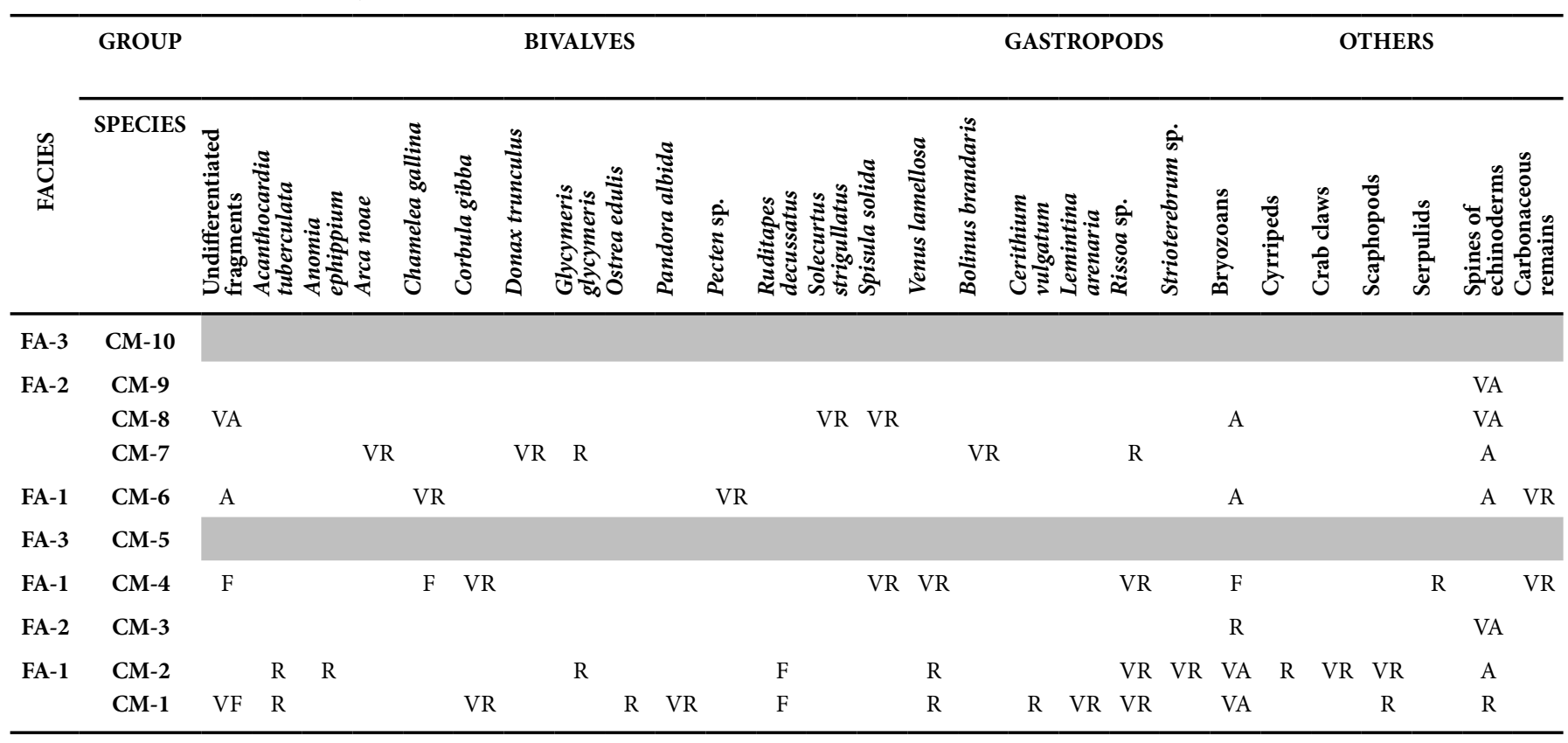

Facies 2 (FA-2: greyish to greenish clay). This facies is characterized by the abundance of very fine sediments (Figure 2 b: clay $~ 70 \%$ ) with grayish to greenish colors (5Y 4/2). More than $50 \%$ of the dry weight is composed of particles between $4 \mu \mathrm{m}$ and $1 \mu \mathrm{m}$. The macrofauna record is very variable, with frequent unclassifiable fragments of bivalves, isolated valves of marine bivalves (Glycymeris glycymeris, Donax trunculus, Solecurtus strigillatus) and gastropods (Bolinus brandaris, Rissoa sp.), as well as very abundant bryozoans and numerous spines of echinoderms (Table 1). Undifferentiated fragments of carbonaceous stems and roots have also been found. The foraminiferal record is abundant, with frequent specimens of Ammonia tepida, Entzia macrescens, Haynesina germanica and Trochammina inflata.

The palaeontological record includes low densities of a high brackish ostracod assemblage (mainly C. torosa, Loxoconcha elliptica and Leptocythere castanea). These species and the foraminiferal record are characteristic of a low marsh or the surrounding margins of a brackish lagoon (Montenegro and Pugliese, 1996; González-Regalado et al., 2001).

Facies 3 (FA-3: yellow sand). This facies is present in two layers inside the CM core (Figure 2a). These layers consist of well sorted, fine to very fine sand (Figure $2 \mathrm{~b}$ : Fine + very fine sand $>60 \%$ ) with intense yellow shades (10Y 8/6). The lower bed shows a lower erosive contact with FA-1, with some silty clasts near the base. In the upper layer of core $\mathrm{CM}$, this facies exhibits cross stratification. Both macrofauna and microfauna are absent.

This facies constitutes the dune systems of the Doñana spit. The ocurrence of the basal sandy layer over FA-1 (Figure 2: $17.5 \mathrm{~m}$ depth) may be indicative of old tsunamis, with a partial rupture or erosion of the spit, the formation of washover fans in its inner side and the sandy sediment deposition in the lagoon. The textural features of this layer, the absence of sedimentary structures, its erosive base, the presence of clasts and the vertical disposition of facies in core CM support this palaeoenvironmental interpretation. In other Holocene sedimentary sequences, this presence of sandy sediments on previous silt-clayey substrates of coastal lagoons has also been interpreted as evidence of ancient tsunamis (Switzer et al., 2006). In a second episode, these washover fans would be reworked by the tidal fluxes and deposited on the margins of old tidal channels or on the lagoon margins, constituting the sandy ridges of Vetalengua (Figure 1), with very similar sedimentological features (Ruiz et al., 2004).

\section{Geochemistry}

The basal lagoonal silts of FA-1 are not contaminated by heavy metals (Figure $2 \mathrm{c}:<15 \mathrm{mg} \cdot \mathrm{kg}^{-1}$ ). These unpolluted sediments are overlaid by slightly polluted marsh clays of FA-2, with some trace metal contents (As: $15 \mathrm{mg} \cdot \mathrm{kg}^{-1}$; $\mathrm{Cu}: 46 \mathrm{mg} \cdot \mathrm{kg}^{-1}$; Ni: $31 \mathrm{ppm}$; Pb: $46 \mathrm{mg} \cdot \mathrm{kg}^{-1}$; Sc: $11 \mathrm{mg} \cdot \mathrm{kg}^{-1}$; Zn: $\left.74 \mathrm{mg} \cdot \mathrm{kg}^{-1}\right)$ above the geochemical background of the Doñana National Park (Carretero et al., 2011). The concentrations of the remaining elements are very close to this background.

Transition to a new layer of FA-1 is characterized by a decrease in trace metals. Only $\mathrm{Pb}$ slightly exceeds the mentioned background $\left(21 \mathrm{mg} \cdot \mathrm{kg}^{-1}\right)$ in the basal part of this layer. Consequently, trace metals

Table 2. Data base of ${ }^{14} \mathrm{C}$ samples and results. Marine reservoir effect correction $\left(\Delta \mathrm{R}=-108 \pm 31{ }^{14} \mathrm{C}\right.$ years $)$.

\begin{tabular}{ccccccccccc}
\hline Sample & $\begin{array}{c}\text { Depth } \\
(\mathrm{m})\end{array}$ & Facies & Phase & $\begin{array}{c}\text { Laboratory } \\
\text { code }\end{array}$ & $\begin{array}{c}{ }^{14} \mathrm{C} \text { age } \\
(\mathrm{BP})\end{array}$ & ${ }^{13} \mathrm{C} /{ }^{12} \mathrm{C}$ & $\begin{array}{c}\text { Calibrated age } \\
(\mathrm{cal} \mathrm{BP})(1 \sigma)\end{array}$ & $\begin{array}{c}\text { Calibrated age } \\
(\mathrm{cal} \mathrm{BP})(2 \sigma)\end{array}$ & $\begin{array}{c}\text { Calibrated age } \\
(\mathrm{cal} \mathrm{BCE} / \mathrm{cal} \mathrm{CE})(1 \sigma)(\mathrm{cal} \mathrm{BCE} / \mathrm{cal} \mathrm{CE})(2 \sigma)\end{array}$ \\
\hline $\mathrm{CM}-6$ & 11.7 & 1 & 3 & Beta-228873 & $2030 \pm 40$ & 0.7 & $1805-1665$ & $1590-1860$ & $145-285 \mathrm{cal} \mathrm{CE}$ & $90-360 \mathrm{cal} \mathrm{CE}$ \\
$\mathrm{CM}-1$ & 31 & 1 & 1 & Beta-228876 & $2830 \pm 40$ & $0.7-$ & $2770-2675$ & $2840-2565$ & $820-725 \mathrm{cal} \mathrm{BCE}$ & $890-615 \mathrm{cal} \mathrm{BCE}$ \\
\hline
\end{tabular}


accumulated progressively in the salt marshes of this old lagoon (FA-2), whereas the lagoon bottom (FA-1) remained unpolluted. The marsh sediments behaved as a partial sink for the studied trace elements, a common process in littoral systems (Ruiz, 2001).

This marsh-lagoon bottom alternation is suddenly interrupted by the sandy deposits of FA-3 coming from the erosion of dune systems. These coarser, tsunamigenic sediments present the lowest values of trace metals as a distinctive feature $\left(\leq 10 \mathrm{mg} \mathrm{kg}^{-1}\right)$. They are very similar to those observed in the uppermost layer of the same aeolian facies (Figure 2c) and other Upper Pleistocene-Holocene aeolian formations of the Doñana National Park (Pozo et al., 2013). Thus, trace metals and other sedimentary characteristics can be used as sentinels of tsunamis in coastal areas (Jayawardana et al., 2012).

This sandy layer is overlaid by silty (FA-1) and clayey (FA-2) sediments. Silty sediments show a trace metal enrichment (As: $16 \mathrm{mg} \cdot \mathrm{kg}^{-1}$; $\mathrm{Cr}: 35 \mathrm{mg} \cdot \mathrm{kg}^{-1}$; Pb: $25 \mathrm{mg} \cdot \mathrm{kg}^{-1}$; Zn: $46 \mathrm{mg} \cdot \mathrm{kg}^{-1}$ ) in the relation with the lower beds of the same facies, surpassing the local background in some cases $(\mathrm{As}, \mathrm{Pb})$. This would imply a first, slight contamination of the lagoon bottom. On the other hand, the upper layer of FA-2 presents a small increase of trace metals towards the top (Cr: $72-78 \mathrm{mg} \cdot \mathrm{kg}^{-1}$; $\mathrm{Cu}: 30-33 \mathrm{mg} \cdot \mathrm{kg}^{-1}$; Pb: 35-41 mg.kg-1 ${ }^{-1} \mathrm{Ni}: 30-35 \mathrm{mg} \cdot \mathrm{kg}^{-1}$; Pb: 71-81 $\left.\mathrm{mg} \cdot \mathrm{kg}^{-1}\right)$. All this would indicate the increase of metallic contributions to this area during the deposit of these last two facies.

\section{Dating and sedimentation rates}

These facies were deposited 3000 years ago, according to the ${ }^{14} \mathrm{C}$ calibrated age of the basal facies (Table 2 and Figure 3: sample CM-1). An additional dating obtained at $12 \mathrm{~m}$ depth (CM-6: 90-360 cal CE) allows an approximation to the age of the tsunamigenic layer (or layers; see next chapter).

Consequently, the lower part of CM core presents a very high sedimentation ratio (Figure 3; mean $>15 \mathrm{~mm} \cdot \mathrm{yr}^{-1}$ ), according to the two dates, although this rate could have been partially increase due to the rapid deposition of FA-3. These high values are not uncommon in lagoons, with sedimentation rates higher than $14 \mathrm{~mm} \cdot \mathrm{yr}^{-1}$ in some of them (Levy, 1978; Pustelnikovas, 2008).

Palaeoenvironmental evolution: historical tsunamis and pollution

The vertical arrangements of facies, its contents in trace elements and the chronology mentioned above delimit three phases in the temporal evolution of core CM (Figure 4):

Phase 1 ( 890 BCE-218 BCE). In this phase, the Doñana National Park was a lagoon (Ruiz et al., 2004), with a wide mouth next to which the studied core was located. This area was situated very close to the inner part of the Doñana spit, with a periodic transition from submerged environments (FA-1) to salt marshes (FA-2) and conversely. This protected scenario explains the presence of fine to very fine sediments and the coexistence of both marine and brackish species, a common feature of lagoonal outlets (Salel et al., 2016).

The external bottom sediments of this lagoon were slightly contaminated by some trace metals (mainly $\mathrm{Cu}, \mathrm{Pb}$, and $\mathrm{Zn}$ ). These elements would come from fluvial contributions that would collect discharges from northern mining areas. These discharges have contaminated this lagoon since the beginning of the Phoenician colonization (> $3 \mathrm{kyr}$ ago; Carretero et al., 2011).

Phase 2 (218 BCE-90 CE). The textural, palaeontological, and geochemical features of the lower sandy layer are indicative of a tsunami or a set of tsunamis. During this tsunamigenic period, a high-energy event (or events) eroded the dune systems of an old shorter Doñana spit and deposited these aeolian sediments on the lagoon bottom, according to its sandy composition, the absence of paleontological record and its scarce metallic content. This possible washover fan

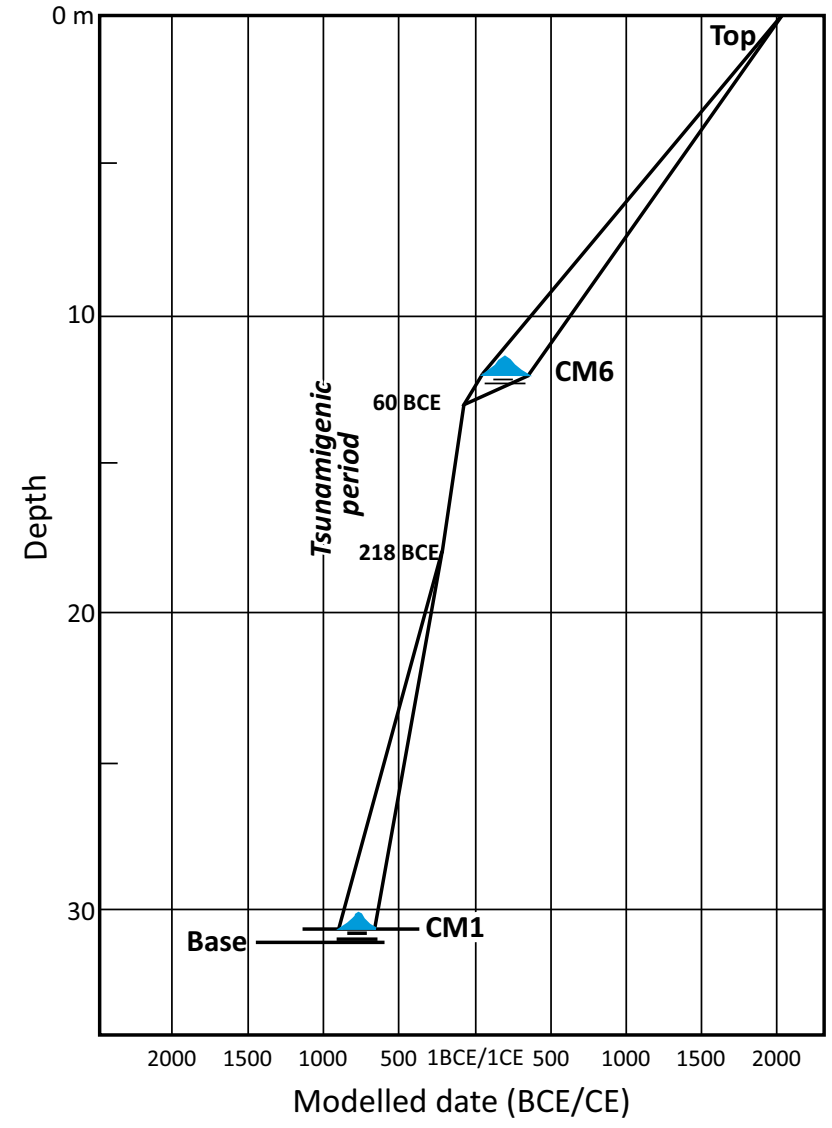

Figure 3. Age model of core CM.

would be redistributed later by tidal cycles and would constitute sandy ridges parallel to the coastline, such as Vetalengua (Figure 1) (Ruiz et al., 2004).

In southwestern Spain, the historical record of tsunamis includes three or four tsunamis between $218 \mathrm{BCE}$ and $60 \mathrm{BCE}$, a chronology that agrees with the suggested chronological boundaries of Phase 2 and with the overlying FA-1 (90 CE-360 CE). In this old lagoon, these tsunamis generated overwash deposits, ebb tide deltas, sand sheets, a bioclastic beach on the lagoon shore (Rodríguez-Vidal et al., 2011b), as well as washover fans in adjacent estuaries (Luque et al., 2002).

Phase 3 (90 CE-Present). This phase is characterized by a regressive sequence: bottom lagoon (FA-1) - marsh (FA-2) - dune system (FA-3). The regional progradation phases $\mathrm{H}_{3}(2300-1100$ cal yr BP) and $\mathrm{H}_{4}(800 \mathrm{cal}$ yr BP-Present) caused the growing of the Doñana spit (Figure 1; Zazo et al., 1994), the progressive limitation of tidal flows, the emersion of the lagoon bottom (FA-1), the subsequent implantation of marshlands (FA-2) and the final development of dune systems (FA-3). This sedimentary sequence has also been observed in the final part of present-day sandy spits in continuous growth (Schwimmer and Pizzuto 2000).

Trace metal concentrations increased, and the bottom sediments were also slightly polluted. During the earlier period of this phase (90 CE-500 CE), the Romans exploited the Iberian Pyrite Belt to obtain mainly copper and silver and some mines and its tailings were located in the basin of de Guadalquivir River (Pérez Macías and Delgado, 2014). These new mining activities would explain this increase, which has also been found in other estuarine sediments of similar age in southwestern Spain (Ruiz et al., 2008). 


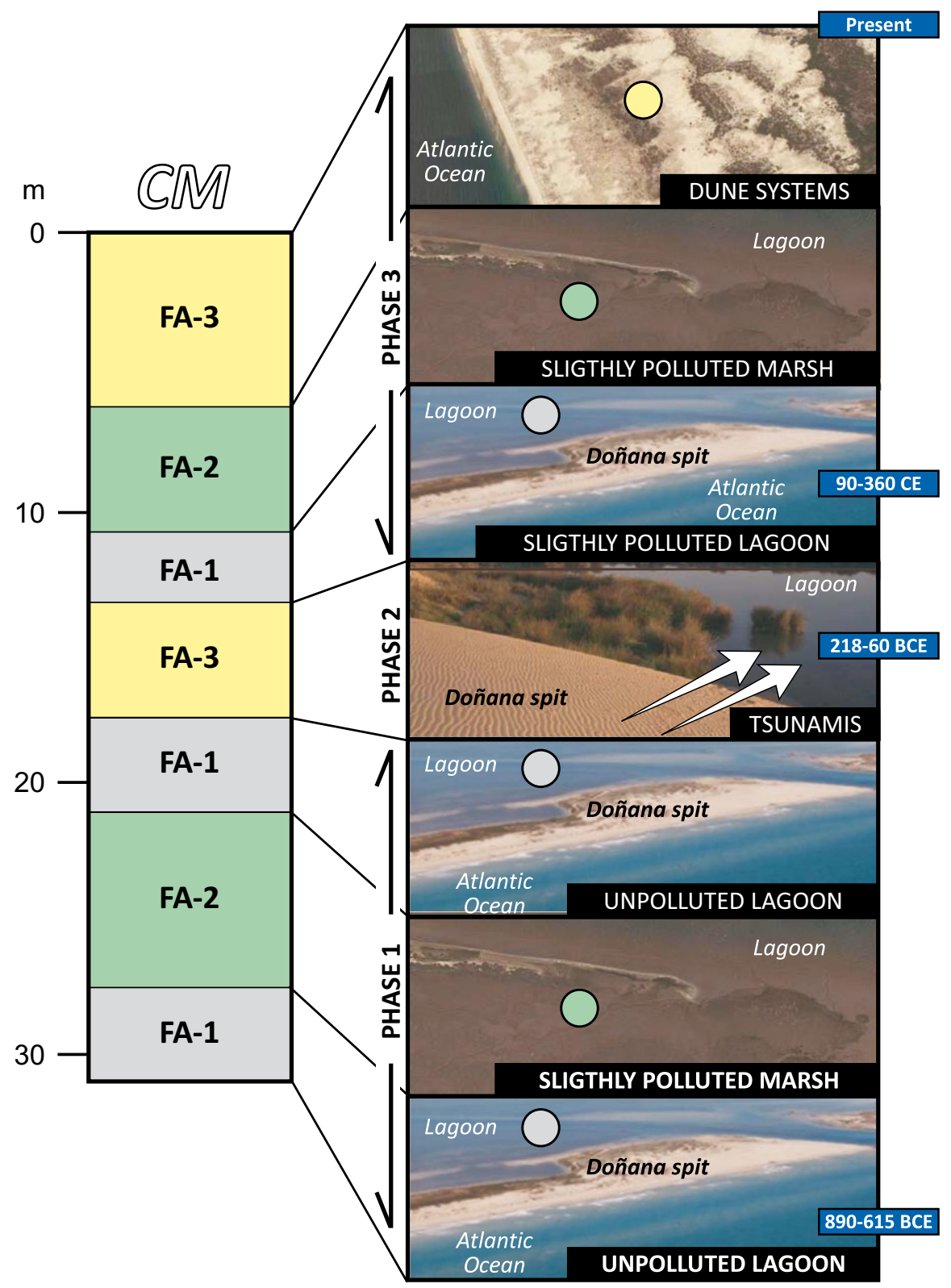

Figure 4. Paleoenvironmental evolution of core CM.

\section{CONCLUSIONS}

A general scenario for Late Holocene-Present evolution of the Doñana spit (SW Spain) has been proposed, based on a multidisciplinary analysis (texture, trace metals, Palaeontology, and dating) of sediments present in a long drill core. The overall study permits to delimitate three main phases during the last 3000 years, with an initial alternation of submerged bottom sediments and salt marshes interrupted by the 218 BCE- 60 BCE tsunamigenic period. During this period, three or four high-energy events caused the erosion of previous dune systems, with the deposit of unpolluted sands on lagoonal silts. The final phase included a regressive sequence, with the final implantation of the present-day dune systems.

The vertical distribution of heavy metals shows the first level of small enrichment by mining activities before $900 \mathrm{BCE}$, especially in marsh deposits. This metal pollution increased during the Roman period, with a little contamination even in the lagoon sediments. Conversely, the tsunami deposits derived from adjacent coastal dune systems are characterized by very low metal contents. Consequently, the geochemical content can be used to differentiate tsunamigenic deposits, in addition to other geological features (texture, palaeontology, chronology).

\section{ACKNOWLEDGEMENTS}

This work has been carried out through the following projects: a) DGYCIT project CTM2006-06722/MAR; b) DGYCIT project CGL2006-01412; c) 'Roman cities of the Baetica. CORPVS VRBIVM BAETICARVM (I) (CUB)' (Andalusian Gouvernement); and d) 'From 
the Atlantic to the Tyrrhenian. The hispanic ports and their commercial relations with Ostia Antica. DEATLANTIR II - HAR2017-89154-P (Plan Nacional de I+D+i). Other funds have come from Andalusian Government (groups HUM-132, RNM-238 and RNM-293). It is a contribution to the Centro de Investigación en Patrimonio Histórico, Cultural y Natural (CIPHCN) of the Universidad de Huelva.

\section{REFERENCES}

Bianchette, T.A., McCloskey, T.A., Liu, K-B., 2016, Re-Evaluating the Geological Evidence for Late Holocene Marine Incursion Events along the Guerrero Seismic Gap on the Pacific Coast of Mexico: PLoS ONE, 11, e0161568.

Borrego, J., Morales, J.A., Pendón, J.G., 1993, Elementos morfodinámicos responsables de la evolución reciente del estuario bajo del río Guadiana (Huelva): Geogaceta, 11, 86-89.

Carretero, M.I., Ruiz, F., Pozo, M., Rodríguez-Vidal, J., Muñoz Pichardo, J.M., Cáceres, L.M., Gómez, F., Campos, J.M., González-Regalado, M.L., Olías, M., 2011, Trace Elements in Holocene Sediments of the Southern Doñana National Park (SW Spain): Historical Pollution and Applications: Environmental Earth Sciences, 64, 1215-1223.

Chagué-Goff, C., 2010, Chemical signatures of palaeotsunamis: A forgotten proxy?: Marine Geology, 271, 67-71.

Costa, P.J.M., Andrade, C., Cascalho, J., Dawson, A.G., Freitas, M.C., Paris, R., Dawson, S., 2015, Onshore tsunami sediment transport mechanisms inferred from heavy mineral assemblages: The Holocene, 25, 795-809.

Cuena, G.J., 1991, Proyecto de regeneración de las playas de Isla Cristina: Memoria: Madrid, Spain, Ministerio de Obras Públicas y Turismo, 100 pp.

Davis, R.A., Welty, A.T., Borrego, J., Morales, J.A., Pendón, J.G., Ryan, J.G., 2000, Rio Tinto estuary (Spain): 5000 years of pollution: Environmental Geology, 39, 1107-1116.

Dawson, A.G., Steward, I., 2007, Tsunami deposits in the geological record: Sedimentary Geology, 200, 166-183.

Engel, M., Brückner, H., 2011, The identification of palaeo-tsunami deposits - a major challenge in coastal sedimentary research: Coastal Reports, 17, 65-80

González-Regalado, M.L., Ruiz, F., Baceta, J.I., González-Regalado, E., Muñoz, J.M., 2001, Total benthic foraminifera assemblages in the southwestern Spanish estuaries: Geobios, 34, 39-51.

Hunt, M.A., 2003, Prehistoric Mining and Metallurgy in South-West Iberian Peninsula: Oxford, Archaeopress, $418 \mathrm{pp}$.

Jayawardana, D., Pitawala, H.M.T.G.A., Ishiga A., 2012, Geochemistry of surface sediments in tsunami-affected Sri Lankan lagoons and environmental implications: International Journal of Environmental Science and Technology, 9, 41-55.

Lario, J., Zazo, C., Goy, J.L., Silva, P.G., Bardají, T., Cabero, A., Dabrio, C.J., 2011, Holocene palaeotsunami catalogue of SW Iberia: Quaternary International, 242, 196-200.

Latcharote, P., Al-Salem, K., Suppasri, A., Pokavanich, T., Toda, S., Jayaramu, Y., Al-Enezi, A., Al-Ragum, A., Imamura, F., 2018, Tsunami hazard evaluation for Kuwait and Arabian Gulf due to Makran Subduction Zone and Subaerial landslides: Natural Hazards, 93, 127-152.

Levy, J., 1978, Comparison of texture, mineralogy and organic content of suspended, accumulating, and bottom sediments within a coastal lagoon, Stone Harbor, New Jersey: Bethlehem, PA, USA, Lehigh University, M.S. thesis, $56 \mathrm{pp}$

Luque, L., Lario, J., Civis, J., Silva, P.G., Zazo, C., Goy, J.L., Dabrio, C.J., 2002, Sedimentary record of a tsunami during Roman times, Bay of Cadiz, Spain: Journal of Quaternary Sciences, 17, 623-631.

Mamo, B., Strotz, L., Dominey-Howes, D., 2009, Tsunami sediments and their foraminiferal assemblages: Earth-Science Reviews, 96, 263-278.

Martins, J.M.M., Soares, A.M.M., 2013, Marine radiocarbon reservoir effect in Southern Atlantic Iberian coast. Radiocarbon, 55, 1123-1134.

Montenegro, M.E., Pugliese, N., 1996, Autoecological remarks on the ostracod distribution in the Marano and Grado Lagoons (Northern Adriatic Sea, Italy): Bolletino della Società Paleontologica Italiana, 3, 123-132.

Nelson, A.R., Briggs, R.W., Dura, T., Engelhart, S.E., Gelfenbaum, G., Bradley, L.A., Forman, S.L., Vane, C.H., Kelley, K.A., 2015, Tsunami recurrence in the eastern Alaska-Aleutian arc: A Holocene stratigraphic record from
Chirikof Island, Alaska: Geosphere, 11, 1172-1203.

Ögretmen, N., Cosentino, D., Gliozzi, E., Cipollari, P., Iadanza, A., Yildirim, C., 2015, Tsunami hazard in the Eastern Mediterranean: geological evidence from the Anatolian coastal area (Silifke, southern Turkey): Natural Hazards, 79, 1569-1589.

Olías, M., Nieto, J.M., 2015, Background conditions and mining pollution throughout history in the Río Tinto (SW Spain): Environment, 2, 295-316.

Pérez Macías, J.A., Delgado, A., 2014, La minería romana en el suroeste ibérico: CPAG, 24, 239-265.

Pozo, M., Ruiz, F., Carretero, M.I., Rodríguez-Vidal, J., Cáceres, L.M., Abad, M., González-Regalado, M.L., 2010, Mineralogical assemblages, geochemistry and fossil associations of Pleistocene-Holocene complex siliciclastic deposits from the Southwestern Donana National Park (SW Spain): A palaeoenvironmental approach: Sedimentary Geology, 225, 1-18.

Pozo, M., Carretero, M.I., Ruiz, F., Olías, M., Abad, M., Rodríguez-Vidal, J., Cáceres, L.M., Prudencio, M.I., Dias, M.I., Font, E., Muñoz, A.M., Izquierdo, T., Toscano, A., 2013, Geochemistry of Lower PlioceneHolocene Formations of Doñana National Park, in Sanjurjo-Sánchéz, J. (ed.), Advances in Geochemistry Research, Series: Geology and Mineralogy Research Developments, Earth Sciences in the 21st Century: New York, Novinka, 1-10.

Pustelnikovas, O., 2008, On the Eastern Baltic environment changes: a case study of the Curonian Lagoon area: Geologija, 50, 80-87.

Putra, P.S., 2018, Tsunami sediments and their grain size characteristics: IOP Conf Ser Earth Environment Sciences, 118, 012035.

Reimer, P.J., Bard, E., Bayliss, A., Beck, J.W., Blackwell, P.G., Bronk Ramsey, C., Buck, C.E., Cheng, H., Edwards, R.L., Friedrich, M., 2013, IntCal13 and Marine13 Radiocarbon Age Calibration Curves, 0-50,000 Years cal BP: Radiocarbon, 55, 1869-1887.

Rodríguez-Vidal, J., Cáceres, L.M., Abad, M., Ruiz, F., González-Regalado, M.L., Finlayson, C., Fynlayson, G., Fa, D., Rodríguez-Llanes, J.M., Bailey, G., 2011a, The recorded evidence of AD 1755 Atlantic tsunami on the Gibraltar coast: Journal of Iberian Geology, 37, 177-193.

Rodríguez-Vidal, J., Ruiz, F., Cáceres, L.M., Abad, M., González-Regalado, M.L., Pozo, M., Carretero, M.I., Monge, A.M., Gómez, F., 2011b, Geomarkers of the 218-209 BC Atlantic tsunami in the Roman Lacus Ligustinus (SW Spain): A palaeogeographical approach: Quaternary International, 242, 201-212.

Rodríguez-Vidal, J., Bardají, T., Zazo, C., Goy, J.L., Borja, F., Dabrio, C.J., Lario, J., Cáceres L.M., Ruiz, F., Abad, M., 2014, Coastal dunes and marshes in Doñana National Park, in Gutiérrez, F., Gutiérrez, M. (eds), Landscapes and Landforms of Spain: Dordrecht, Springer, 229-238.

Ruiz, F., 2001, Trace metals in estuarine sediments from the southwestern Spanish coast: Marine Pollution Bulletin, 42, 482-490.

Ruiz, F., Rodríguez-Ramírez, A., Cáceres, L.M., Rodríguez-Vidal, J., Carretero, M.I., Clemente, L., Muñoz, J.M., Yañez. C., Abad. M., 2004. Late Holocene evolution of the southwestern Doñana Nacional Park (Guadalquivir Estuary, SW Spain): a multivariate approach: Palaeogeography, Palaeoclimatology, Palaeoecology, 204, 47-64.

Ruiz, F., Rodríguez-Ramírez, A., Cáceres, L.M., Rodríguez-Vidal, J., Carretero, M.I., Abad, M., Olías, M., Pozo, M., 2005, Evidence of high-energy events in the geological record: Mid-Holocene evolution of the southwestern Doñana National Park (SW Spain): Palaeogeography, Palaeoclimatology, Palaeoecology, 229, 212-229.

Ruiz, F., Abad, M., Galán, E., González, I., Aguilá, I., Olías, M., Gómez Ariza, J.L., Cantano, M., 2006a. The present environmental scenario of El Melah Lagoon (NE Tunisia) and its evolution to a future sabkha: Journal of African Earth Sciences, 44, 289-302.

Ruiz, F., Abad, M., Olías, M., Galán, E., González, I., Aguilá, E., Hamoumi, N., Pulido, I., Cantano, M., 2006b. The present environmental scenario of the Nador Lagoon (Morocco): Environmental Research, 102, 215-229

Ruiz, F., Borrego, J., González-Regalado, M.L., López-González, N., Carro, B., Abad, M., 2008, Impact of millenial mining activities on sediments and microfauna of the Tinto River estuary (SW Spain): Marine Pollution Bulletin, 56, 1258-1264.

Ruiz, F., Abad, M., Cáceres, L.M., Rodríguez-Vidal, J., Carretero, M.I., Pozo, M., González-Regalado, M.L., 2010. Ostracods as tsunami tracers in Holocene sequences: Quaternary Research, 73, 130-135.

Ruiz, F., Rodríguez-Vidal, J., Abad, M., Cáceres, L.M., Carretero, M.I., Pozo, 
M., Rodríguez-Llanes, J.M., Gómez-Toscano, F., Izquierdo, T., Font, E., Toscano, A., 2013a, Sedimentological and geomorphological imprints of Holocene tsunamis in Southwestern Spain: An approach to establish the recurrence period: Geomorphology, 203, 97-104.

Ruiz, F., Abad, M., Pozo, M., Carretero, M.I., Rodríguez-Vidal, J., Cáceres, L.M., Font, E., González-Regalado, M.L., Toscano. A., García, E.X., 2013b, Evolución paleoambiental del sector meridional del Parque Nacional de Doñana desde el Plioceno Inferior a la actualidad: Estudios Geológicos, $69,173-177$.

Salel, T., Bruneton, H., Lefèvre, D., 2016, Ostracods and environmental variability in lagoons and deltas along the north-western Mediterranean coast (Gulf of Lions, France and Ebro delta, Spain): Révue de Micropaléontologie, $59,425-444$.

Sánchez, M.E., Contreras, E., Aguilar, C., Polo, M.J., 2012, Extreme values of fluvial discharges to the Guadalquivir estuary as affected by precipitation and regulation upstream: Geophysical Research Abstracts, 14, EGU2012-10638.

Schwimmer, R.A., Pizzuto, J.E., 2000, A Model for the Evolution of Marsh Shorelines: Journal of Sedimentary Research, 70, 1026-1035.

Switzer, A.D., Bristow, C.S., Jones, B.G., 2006, Investigation of large-scale washover of a small barrier system on the southeast Australian coast using ground penetrating radar: Sedimentary Geology, 183, 145-156.
Veerasingam, S., Venkatachalapathy, R., Basavaiah, N., Ramkumar, T., Venkatramanan, S., Deenadayalan, K., 2014. Identification and characterization of tsunami deposits off southeast coast of India from the 2004 Indian Ocean tsunami: Rock magnetic and geochemical approach: Journal of Earth System Sciences, 123, 905-921.

Xu, F., Hu, B., Dou, Y., Song, Z., Liu, X., Yuan, S., Sun, Z., Li, A., Yin, X., 2018, Prehistoric heavy metal pollution on the continental shelf off Hainan Island, South China Sea: from natural to anthropogenic impacts around 4.0 kyr BP: The Holocene, 28, 455-463.

Zazo, C., Goy, J.L., Somoza, L., Dabrio, C.J., Belluomini, G., Improta, S., Lario, J., Bardají, T., Silva, P.G., 1994, Holocene sequence of sea-level fluctuations in relation to climatic trends in the Atlantic-Mediterranean linkage coast: Journal of Coastal Research, 10, 933-945.

Manuscript received: august 23, 2018

Corrected manuscript received: august 28, 2019

Manuscript accepted: august 28, 2019 